\title{
Non-Invasive Measurement of Cortisol Metabolite in Feces of Toraya Buffalo by Using Enzyme Immunoassay Technique
}

\author{
Gholib Gholib ${ }^{1 *}$, Fatri H.R.A. Pampang ${ }^{2}$, Triva M. Lubis ${ }^{1}$, Mulyadi Adam ${ }^{1}$, Muhammad Jalaluddin ${ }^{3}$, Razali Razali $^{4}$, \\ Azhar-Azhar ${ }^{1}$, Teuku F. Karmil ${ }^{5}$ \\ ${ }^{1}$ Physiology Laboratory, Faculty of Veterinary Medicine, Universitas Syiah Kuala, Banda Aceh, Aceh, Indonesia \\ ${ }^{2}$ Study Program of Veterinary Education, Faculty of Veterinary Medicine, Universitas Syiah Kuala, Banda Aceh, Aceh, Indonesia \\ ${ }^{3}$ Anatomy Laboratory, Faculty of Veterinary Medicine, Universitas Syiah Kuala, Banda Aceh, Aceh, Indonesia \\ ${ }^{4}$ Public Health Laboratory, Faculty of Veterinary Medicine, Universitas Syiah Kuala, Banda Aceh, Aceh, Indonesia \\ ${ }^{5}$ Clinic Laboratory, Faculty of Veterinary Medicine, Universitas Syiah Kuala, Banda Aceh, Aceh, Indonesia
}

\begin{abstract}
Non-invasive measurement hormones in feces using enzyme immunoassay (EIA) technique needs to be validated. This study was conducted to develop and validate an enzyme immunoassay kit for measuring the concentration of cortisol metabolites in feces of Toraya buffalo. An EIA kit of 11 $\beta$-hydroxyetiocholanolone (11ß-hydroxy-CM assay) was developed and validated analytically and biologically using feces of Toraya Buffalo for cortisol metabolite measurements. Analytical validation comprises the parallelism test, accuracy, precision, and assay sensitivity. Biological validation performed by comparing concentration cortisol metabolites in feces of Toraya buffalo before and after pa'silaga tedong, a fighting contest of buffalo during the death ceremony of rambu solo at Tana Toraja, South Sulawesi Province. Results showed that the curve of serial dilution of fecal samples was parallel with the 11 $\beta$-hydroxy-CM standard curves. The accuracy and sensitivity of the $11 \beta$-hydroxy-CM assay were $96.21 \% \pm 7.59$ and $0.78 \mathrm{pg} / \mathrm{well}$, respectively. The precision based on coefficient variation $(\mathrm{CV})$ of intra- and inter-assay was $<10 \%$ and $<15 \%$, respectively. Biological validation results showed that cortisol metabolites concentrations after pa'silaga tedong were increased 3-10 fold than before pa'silaga tedong. In conclusion, the 11ß-hydroxy-CM assay is a reliable assay for measuring cortisol metabolites in feces of Toraya buffalo.
\end{abstract}

Keywords: Toraya buffalo, cortisol metabolites, $11 \beta$-hydroxy-CM assay, analytical and biological validations.

\section{Introduction}

Toraya buffalo is one of native Indonesian livestock in Indonesia based on a decision letter of the Ministry of Agriculture No. 2845 / Kpts / LB.430 / 8/2012. This buffalo is distributed at Tana Toraja, South Sulawesi, Indonesia. The characteristic of Toraya buffalo can be recognized by the body color which varies from white, black, combination of white and black, and gray. Toraya buffalo is an important livestock for the Toraja people because Toraja ethnic has a traditional ceremony called pa'silaga tedong, a fighting contest of buffalo during the death ceremony of rambu solo [1].

The pa'silaga tedong is an event in which buffalo will be fought with other buffalo before sacrificed for rambu solo ceremony [2]. This event is very famous and many tourists came. However, this event is not in accordance with the principles of animal welfare and can cause stress. Therefore, efforts are needed to monitor the impact of the buffalo fighting on the stress levels for assessing animal welfare. Moreover, information related to stress levels can be used for holding the management of the tradition of buffalo fighting in the future.

Monitoring stress can be assessed through stress hormone measurement such as cortisol. The classic method, measuring cortisol concentration performed from a blood sample as known as an invasive method [3]. However, this method sometimes causes stress on animals due to the process of capturing, sedating, and taking blood samples over a long time, so the measurement data becomes inaccurate [4]. The last few decades have developed a non-invasive method for measuring cortisol hormone from feces or urine samples $[5,6]$.

Measurement of cortisol from feces or urine requires specific antibodies [7]. This is because the hormones measured in feces or urine are hormones that have been metabolized by the body, known as the hormone metabolites. $5 \beta$-androstane $3 \alpha, 11 \beta$-diol-17-CMO-BSA (11 $\beta$-hydroxy etiocholanolo- ne / 11 $\beta$-hydroxy-CM) is an antibody that widely used to measure cortisol metabolite in feces or urine in several animals $[7,8]$. This antibody is a reduction of cortisol hormone by the $5 \beta$ reductase enzyme which can specifically measure cortisol metabolites in animal feces and urine [9]. This type of assay has been successfully applied to measure cortisol metabolites in wildlife animals in Indonesia [10]. However, the use of this assay for measuring cortisol metabolite concentrations in Toray buffalo feces has never been done. Therefore it is necessary to do a validation test to evaluate the ability of the $11 \beta$-hydroxy-

*Corresponding author: gholib@unsyiah.ac.id 
CM assay for cortisol metabolite measurement in Toraya buffalo. Therefore, the present study was conducted to validate 11ß-hydroxy-CM assay analytically and biologically for cortisol metabolite measurement in feces of Toraya buffalo.

\section{Materials and Methods}

\subsection{Fecal sample Collection}

Fecal samples were collected from Toraya buffalo in Makale, Tana Toraja Regency, South Sulawesi. In this study, 20 male Toraya buffaloes (10 fighters and 10 nonfighters buffaloes) were used. A fecal sample was collected immediately after defecation, homogenized, and then 5-10 g was put into a tube and stored in the freezer at $-20^{\circ} \mathrm{C}$ before transported to the Laboratory of Physiology Faculty of Veterinary Medicine, Universitas Syiah Kuala for hormone analysis.

\subsection{Fecal sample preparation and extraction}

Fecal samples were extracted using a method described by Gholib et al. [8]. The first, frozen fecal sample was thawed at $50^{\circ} \mathrm{C}$ for 1-2 hours. Subsequently, the fecal sample was homogeneous and $\sim 0.55 \mathrm{~g}$ of fresh fecal samples were put into a tube containing $4.5 \mathrm{ml}$ of $80 \%$ methanol. Fecal samples were then extracted using a multivortexer (Brand, USA) at a speed of $1000 \mathrm{rpm}$ for 10 minutes. After that, the sample was centrifuged at 3000 rpm for 10 minutes. Finally, the supernatant was taken and put into a microtube and stored in a freezer $-20^{\circ} \mathrm{C}$ before measuring the cortisol metabolite concentration.

\subsection{Validation of Enzyme immunoassay}

Fecal samples were extracted using a method described by Gholib et al. [8]. The first, frozen fecal sample was thawed at $50^{\circ} \mathrm{C}$ for 1-2 hours. Subsequently, the fecal sample was homogeneous and $\sim 0.55 \mathrm{~g}$ of fresh fecal samples were put into a tube containing $4.5 \mathrm{ml}$ of $80 \%$ methanol. Fecal samples were then extracted using a multivortexer (Brand, USA) at a speed of $1000 \mathrm{rpm}$ for 10 minutes. After that, the sample was centrifuged at 3000 rpm for 10 minutes. Finally, the supernatant was taken and put into a microtube and stored in a freezer $-20^{\circ} \mathrm{C}$ before measuring the cortisol metabolite concentration.

\subsection{Validation of Enzyme immunoassay}

A validation test was carried out to examine the ability and accuracy of the $11 \beta$-hydroxy-CM assay for measuring the concentration of cortisol metabolites in fecal samples of Toraya buffalo. The validation test was performed through analytical and biological validations. The procedure of the validation test was adopted from Gholib et al., [11] and Gholib et al. [12]. The analytical validation test consists of the parallelism/linearity test, accuracy, precision, and sensitivity. The parallelism / linearity test was performed by running serial dilution of a fecal extract of Toraya buffalo 1:10 to 1:320 and then assayed together with $5 \beta$-androstane-3 $\alpha, 11 \beta$-diol-17-one standards. After that, the slope of the expected dose versus percent bound of a diluted fecal extract of Toraya buffalo was compared with the slope of $5 \beta$-androstane- $3 \alpha, 11 \beta$ diol-17-one standards). The accuracy was tested by adding known quantities of the hormone to $5 \beta$ androstane-3 $\alpha, 11 \beta$-diol-17-one standards and then calculated the percentage of the recovery. The precision was tested by calculating intra-assay coefficients of variation (measuring some low-quality controls (QC L) and high-quality controls (QC $\mathrm{H})$ in one microplate) and inter-assay CV (measuring some QC L and QC $\mathrm{H}$ in several microplates). The biological validation was performed by examining the effects of a fighting contest of buffalo during the death ceremony of rambu solo on the concentration of cortisol metabolites. For one fighter buffaloes, fecal samples were collected one week before and from the day 1 to 7 after fighting event (pa'silaga tedong). Moreover, fecal samples were also collected from nine fighter buffaloes 2 to 4 weeks after pa'silaga tedong and 10 non fighter buffaloes..

\subsection{Hormone Measurements}

The procedure for measuring cortisol metabolite concentrations in the fecal extract of Toraya buffalo was carried out according to Gholib et al ., [13]. $50 \mu \mathrm{l}$ of fecal extracts, standards, and quality controls were assayed on microplates. Afterward, it was added $50 \mu \mathrm{l}$ enzyme conjugate, and $50 \mu \mathrm{l}$ antibody to each well and then mixed. The mixture was then incubated overnight at $4{ }^{\circ} \mathrm{C}$. Following incubation, the plates were washed four times with PBS washing solution (containing $0.05 \%$ Tween 20), blotted dry, and $150 \mu \mathrm{l}$ of streptavidin-peroxidase (S5512, supplied by Sigma, Germany) in assay buffer was added to each well. The plates were incubated at room temperature (RT) in the dark for 30 minutes after which they were washed again four times. Substrate solution (150 $\mu \mathrm{l}$, containing $0.025 \%$ tetramethyl-benzidine and $0.05 \% \mathrm{H}_{2} \mathrm{O}_{2}$ ) was then added to each well. The plates were again incubated in dark at RT for 30-45 min depending on the color change. The enzyme reaction was then stopped with $50 \mu 12 \mathrm{M} \mathrm{H} 2 \mathrm{SO} 4$ in each well. Finally, absorbance was measured using the ELISA reader (xMark $^{\mathrm{TM}}$ Microplate Absorbance Spectrophotometer, Bio-Rad Laboratories Inc.) at $450 \mathrm{~nm}$.

\subsection{Data Analysis}

Data of the parallelism test were analyzed using the test of equality of slope between the sample curve and the standard curve [14]. The accuracy was determined by calculated the \% recovery (measured hormone concentration / expected hormone concentration x 100). The precision was calculated from the $\% \mathrm{CV}$ of intra and inter-assay from the Low-Quality Control (QC-Low) and High-Quality Control (QC-High) [(standard deviation/average) $\mathrm{x} 100]$. The sensitivity was calculated by subtracting 2 standard deviations from the mean of 20 replicate analyses of the zero standards. The concentration of cortisol metabolites from fighters and non-fighters buffalo were analyzed using the Mann Whitney U Test. 


\section{Results and Discussion}

\subsection{Analytical Validation}

Analytical validation is one of the validation tests conducted to examine the ability of a $5 \beta$ - hydroxy-CM assay for measuring cortisol metabolites in feces of Toraya buffalo accurately. This validation test consists a paralellism test (linierity), accuracy, precision, and sensitivity.

Results of paralellism test showed that fecal cortisol concentartions of diluted fecal samples ( $1: 10$ to 1:320) decreased in line with the increasing of dilution levels (Figure 1). The curve of the serial dilution of fecal samples was parallel with the curve of $5 \beta$ - hydroxy-CM standard which slope of the $5 \beta$ - hydroxy-CM standard curve was not significantly different with the slope of the fecal samples curve $(p>0.05)$. Based on the results of the pararellism test, the optimal dilution for measuring fecal cortisol in feces of toraya buffalo using this assay was 1:50 Parallelism test is a test conducted to determine the linearity of the serial dilution samples to the standard curve of the hormone assay used. This test can used to evaluated the binding capability of the antigen to the antibody in the assay used. Moreover, the parallelism test can also be used to determine the optimal dilution of the sample used [11].

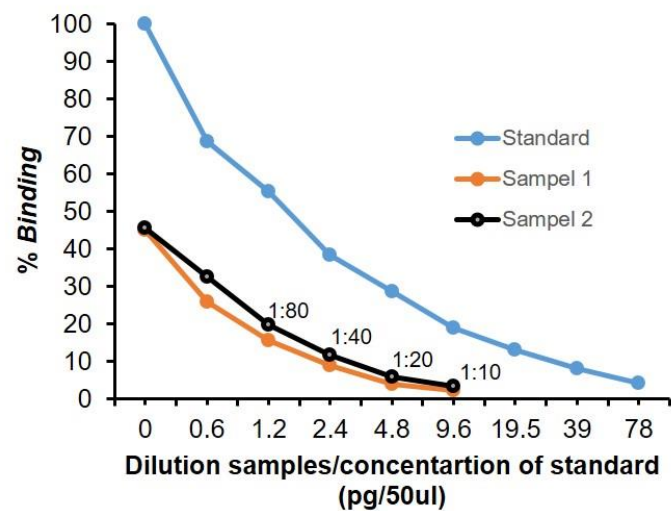

Figure 1. Curve of serial dilution of selected fecal samples (sample 1 and 2 ) and $5 \beta$ - hydroxy-CM standard

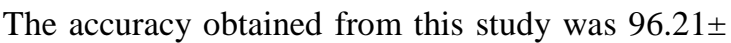
$7.59 \%$. This results indicate that $5 \beta$ - hydroxy-CM assay has a good accuracy for measuring fecal cortisol metabolite in feces of Toraya buffalo. This test can be used to evaluate the interfearing substances that may that may interfere with the binding of antigens and antibodies [15].

The precision of $5 \beta$-hydroxy-CM assay based on the percentage coefficient of variation $(\% \mathrm{CV})$ within plate (intra-assay-CV) and between plates (inter-assay-CV) from Low-Quality control (QC-Low) and High-Quality Control (QC-High) was presented in Table 1. The sensitivity of the $5 \beta$ - hydroxy-CM assay was $0.78 \mathrm{pg} / \mathrm{well}$. Results of the analytical validation showed that this assay a reliable assay for measuring fecal cortisol metabolite in feces of Toraya buffalo.
Table 1. Percentace of coefficient varioation (CV) of intra-and inter-assay variation

\begin{tabular}{lll}
\hline & Intra-assay & Inter-assay \\
\hline High Quality Control (\%0 & 7.08 & 12.65 \\
Low Quality Control (\%) & 8.85 & 9.67 \\
\hline
\end{tabular}

\subsection{Biological Validation}

Fecal cortisol concentrations in feces of Toraya buffalo after fighting showed an increase 3-10 fold compared to before fighting (Figure 2).

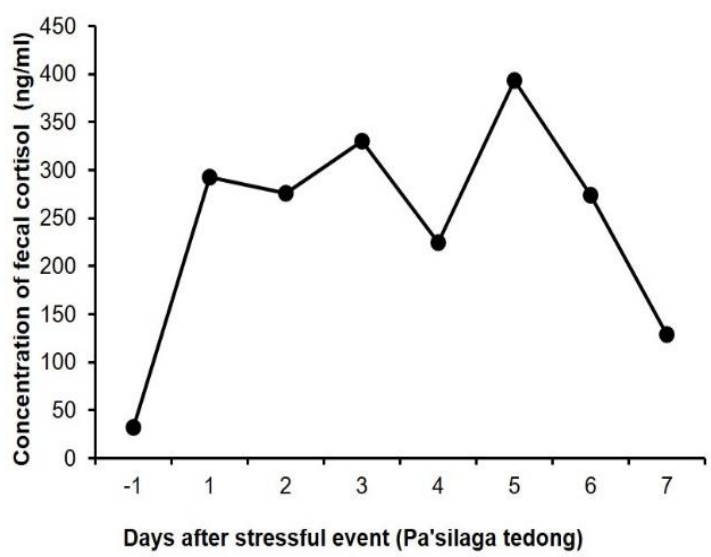

Figure 2. Fecal cortisol concentration of Toraya buffalo before (-1) and after (1 to 7) P'silaga tedong, , a fighting contest of buffalo during the death ceremony of rambu solo at Tana Toraja, South Sulawesi Province.

Comparing before fighting ( day -1), cortisol concentrations on the 1 st day to the 7 th day increased by $825 \%, 770 \%, 941 \%, 609 \%, 1142 \%, 764 \%$ and $307 \%$. On the 4th day, cortisol concentrations seem to decrease, but it increased again on the 5th day after fighting. Increasing of fecal cortisol concentrations is expected due to unhealed wounds yet. Fecal cortisol concentration decreased considerably on the 7 th day, but the fecal cortisol concentrations were still higher than before fight.

The results showed that the concentrations of fecal cortisol in non-fighter's buffalo were lower compared to fighting's buffalo which had been used in the Tedong Pasilaga ceremony. The mean $( \pm$ SD) of fecal cortisol concentrations in non-fighter's buffalo was $124.31 \pm 54.30$ $\mathrm{ng} / \mathrm{g}$ feces, and $201.16 \pm 141.18 \mathrm{ng} / \mathrm{g}$ in figther's buffalo (Figure 3). However, the fecal cortisol concentrations were no significant difference between non-fighter's buffalo and fighter's buffalo $(p>0.5)$. This is likely because the fecal samples from the fighter's Toraya buffalo were collected 2 to 4 weeks after Pa'silaga tedong ceremony, so that the buffalo has undergone a recovery process.

Based on the results indicated that biological validation of $5 \beta$ - hydroxy-CM showed a biological meaningfull regarding in the response to stress event. According to Etim et al. [16], stress can be caused by several factors such as poor maintenance, hunger, thirsty, injury, and hot weather which cortisol can be used as indicator of stress [12]. 


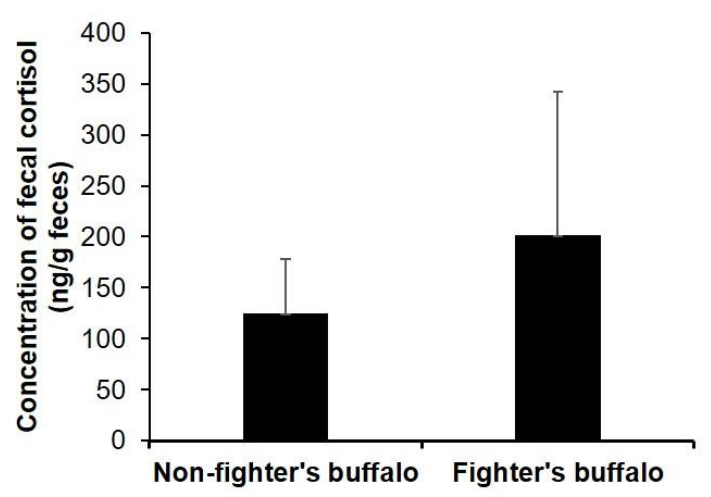

Figure 3. The mean \pm SD fecal cortisol concentrations in nonfighter and fighter of Toraya buffalo

A high increase in the fecal cortisol metabolite concentrations in buffalo after fighting indicated that the buffalo is experiencing stress. When the body receives a stressor, the hypothalamus will secrete corthicotrophinreleasing-hormone $(\mathrm{CRH})$. This hormone will stimulate the anterior pituitary to synthesize and produce adenocorticotrophic hormone (ACTH). ACTH will stimulate the adrenal glands to secrete the hormone cortisol [4].

To improve the fitness of the individual during stress, various endocrine responses are involved which the main of those hormones are glucocorticoids (GCs) and catecholamines [17]. Palme et al. [18] stated that the most important and biologically relevant GCs are cortisol and corticosterone. These hormones are determined as a parameter of adrenal activity [18,19]. Glucocorticoid was synthesized and released from the adrenal cortex which are controlled by the pituitary adrenocorticotrophic hormone (ACTH) and regulated by the hypothalamic corticotrophin-releasing hormone (CRH) [18,19]. However, the processes regulating the secretion of GC are complex [18]. Glucocorticoids improve fitness by energy mobilisation during short-term stress [20] and may change behaviour [21]. However, individual fitness may decrease when severe chronic stress (long periods of high cortisol concentrations) by immunosuppression and a trophy of tissues [23]. Moreover, the reproductive success of the animal is decreased [23].

\section{Conclusion}

In conclusion, the $11 \beta$-hydroxy-CM assay is a reliable assay for measuring cortisol metabolites in feces of Toraya buffalo..

\section{Acknowledgments}

We would like to thanks to Universitas Syiah Kuala for funding this research project through "Hibah Laboratorium Unsyiah 2019". We gratefully acknowledge the permission granted by the Animal Husbandry Department, Tana Toraja Regency, South Sulawesi.

\section{References}

1. Sariubang M, Qomariyah R, Kristanto L: Peranan ternak kerbau dalam masyarakat adat toraja di Sulawesi Selatan. Prosiding dan Lokakarya Nasional Kerbau. 2010 .

2. Rosita, Karim M, Haq N: Strategi pemerintah dalam peningkatan destinasi manajemen organisasi (DMO) pariwisata di Kabupaten Tana Toraja. Jurnal Administrasi Publik. 2016; 2(2):206-218.

3. Brown JL, Wasser SK, Wildt DE, et al. : Comparative aspects of steroid hormone metabolism and ovarian activity in felids, measured noninvasively in feces. Biology Of Reproduction. 1994; 51(4):776-786.

4. Sheriff MJ, Dantzer B, Delehanty B, et al. : Measuring stress in wildlife: techniques for quantifying glucocorticoids. Oecologia. 2011; 166: 869-887.

5. Wasser SK, Risler L, Steiner RA: Excreted steroids in primate feces over the menstrual cycle and pregnancy. Biol Reprod. 1988; 39: 862-872.

6. Millspaugh JJ, Washburn BE: Use of fecal glococorticoid metabolite measures in conversation biology research: considerations for application and interpretation. Gen Comp Endocrinol. 2004; 138: 189-199.

7. Heistermann M, Palme R, Ganswindt A: Comparison of different enzyme immunoassays for assessment of adrenocortical activity in primates basedon fecal analysis. Am J Primatol. 2006; 68: 257-273.

8. Gholib G, Heistermann M, Agil M, et al. : Comparison of fecal preservation and extraction methods for steroid hormone metabolite analysis in wild crested macaques. Primates, 2018, 59 (3):1-12.

9. Ganswindt A, Palma R, Heistermann M, et al. : Non invasive assessment of adrenocortical function in the male african elephant (Loxodonta africana) and its relation to musth. Gen Comp Endocrinol. 2003; 134: 156-166.

10. Nugraha TP, Heistermann M, Agil M, et al.: Validation of a field-friendly extraction and storage method to monitor fecal steroid metabolites in wild orangutans. Primates 58, 2017, (2): 285-294.

11. Gholib, Wahyuni S, Kada OH, et al. : Measurement of serum testoterone in kacang goat by using enzymelinked immunosorbent assay (ELISA) technique: the importance of kit validation. Jurnal Kedokteran Hewan. 2016; 10(1): 32-36.

12. Gholib G, Wahyuni S, Akmal M, et al. : The validation of a commercial enzyme-linked immunosorbent assay and the effect of freeze-thaw cycles of serum on the stability of cortisol and testosterone concentrations in Aceh cattle [version 1; peer review: 1 approved, 1 approved with reservations]. F1000Research 2019, 8:1220.

13. Gholib Gholib, Agil M, Supriatna I, et al. : Repeated freeze-thaw cycles but not short-term storage of fecal extracts at ambient temperature influence the stability of steroid metabolite levels in crested macaques. Jurnal Kedokteran Hewan. 2017; 11: 78-85.

14. Zar JH: Biostatistical Analysis. Prentice Hall. Upper Saddle River. N.J.1996. 
15. Goymann W: Non invasive monitoring of hormones in bird droppings: physiological, validation, sampling, excraction, sex, differences, and the influence of diet on hormone metabolite levels. Ann. NY Acad. Sci. $2005 ; 1046: 35-53$

16. Etim NN, Offiong EEA, Eyoh GD, et al. : Stress and animal welfare: an uneasy relationship. European Journal of Advanced Research in Biological and Life Science. 2013; 1(1):9-16.

17. Möstl E, Palme R: Hormones as indicators of stress. Dom Anim Endocrinol. 2002; 23: 67-74

18. Palme R : Measuring fecal steroids: Guidelines for practical application. Annals of the New York Academy of Sciences. 2005; 1046(1):75-80.

19. Martin PA, Crump MH: The adrenal gland. In: Pineda MH, Dooley MP, editors. Veterinary Endocrinology and Reproduction. $5^{\text {th }}$ Ed. USA: Lowa State Press. pp 165200. 2003.
20. Raynaert R, De Paepe M, Peeters G: Influence of stress, age and sex on serum growth hormone and free fatty acids in cattle. Horm Metab Res. 1976; 8:109-14.

21. Korte SM, Bouws GAH, Bohus B: Central actions of corticotropin-releasing hormone (CRH) on behavioral, neuroendocrine and cardiovascular regulation: brain corticoid receptor involvement. Horm Behav. 1993; 27:167-83.

22. Munck A, Guyre PM, Holbrook NI: Physiological functions of glucocorticoids in stress and their relationship to pharmacological actions. Endocr Rev. 1984; 5:25-44.

23. Hardy MP, Gao HB, Dong Q, et al.: Stress hormone and male reproductive function. Cell Tissue Res. 2005; 322(1):147-153. 